\title{
Notes on the vocalizations of Blue Rock-thrush (Monticola solitarius)
}

\section{Peter Boesman}

In the following we briefly analyze and compare voice of the different races of Blue Rockthrush (Monticola solitarius). We also try to quantify the extent of any vocal differences using the criteria proposed by Tobias et al. (2010), as a support for taxonomic review. We have made use of sound recordings available on-line from Xeno Canto (XC).

Our main interest is to compare voice of distinctive race philippensis with other races. Some examples of song, illustrated with sonograms:

philippensis

short song
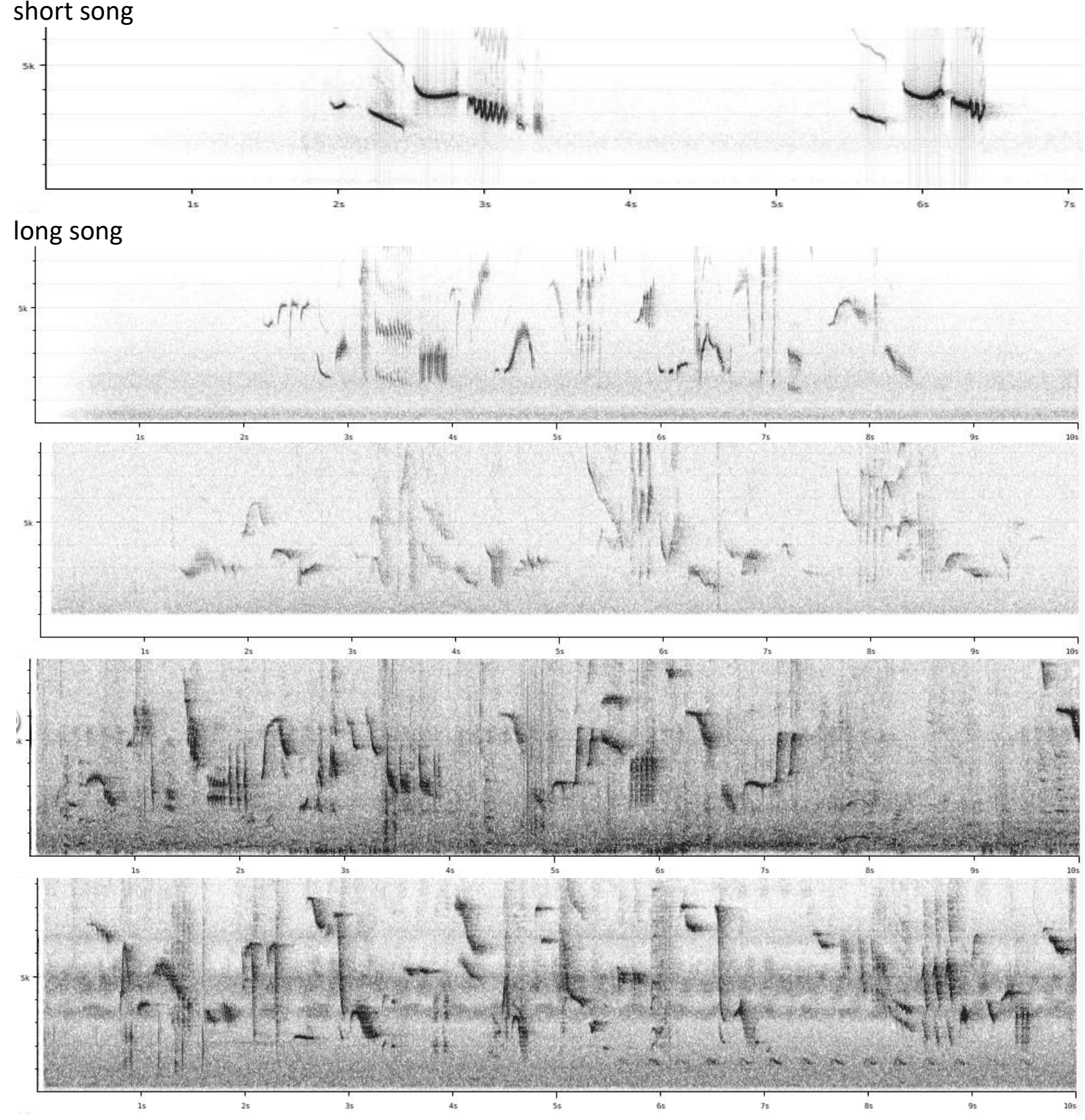


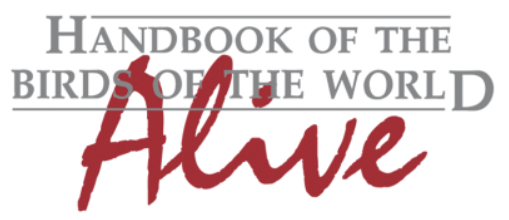

\section{ORNITHOLOGICAL NOTES}

To be compared with e.g. vocalizations from Europe (solitarius):

short song
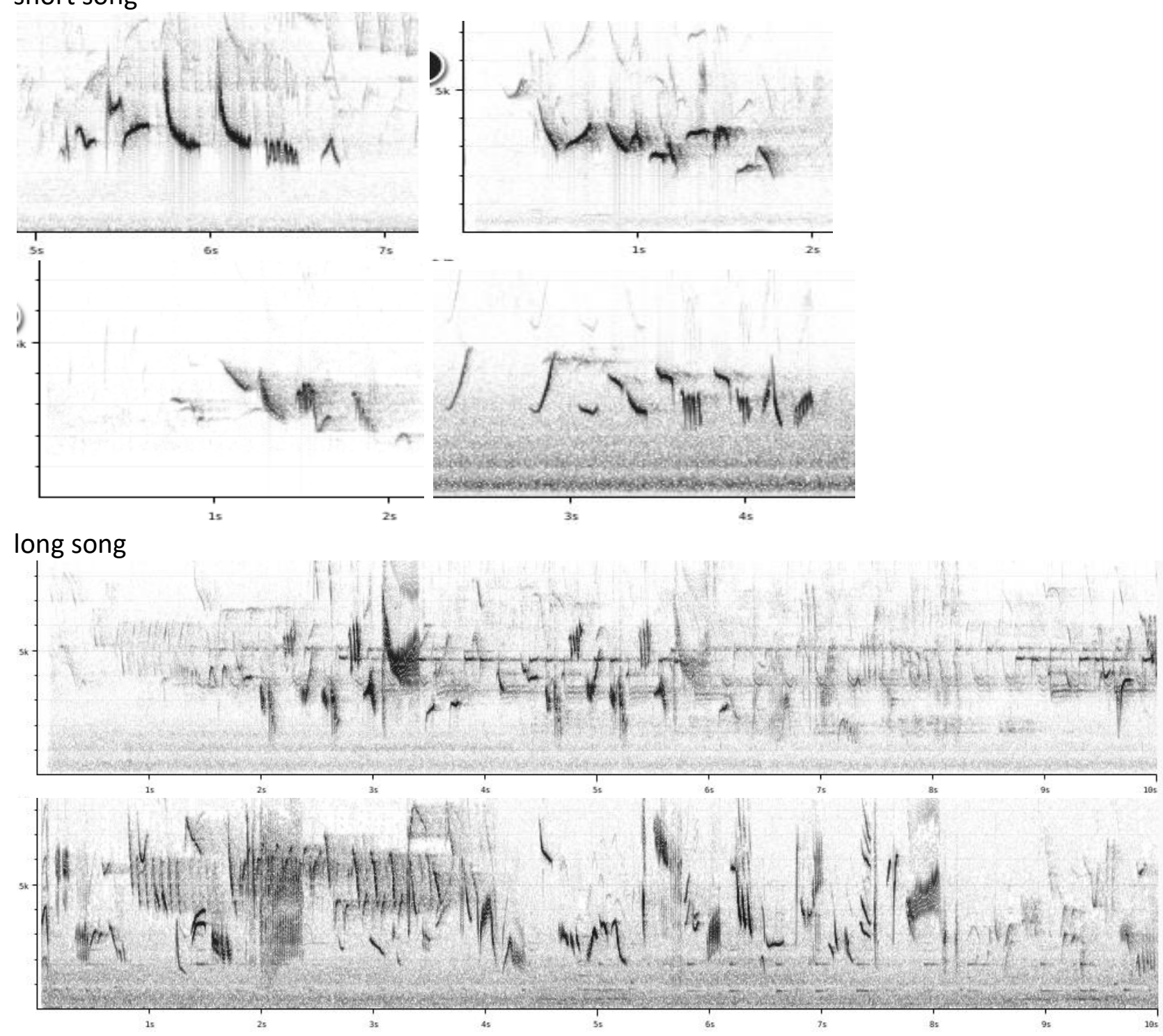

Both groups seem to have a short song and a long song, consisting of similar melodious whistles, trills and more burry notes.

Overall, vocalizations are quite similar. All basic sound parameters largely overlap (phrase duration, note length, min./max. frequency,..). Even many note shapes are identical.

Based on the number of available recordings, the long song seems to be much more common in Japan than e.g. in Europe (which confirms statement in HBW Alive: Collar 2016).

Other than that, we have not found any obvious vocal differences of race philippensis. 
This note was finalized on 11th May 2016, using sound recordings available on-line at that moment. We would like to thank in particular the many sound recordists who placed their recordings for this species on XC.

\section{References}

Collar, N. (2016). Blue Rock-thrush (Monticola solitarius). In: del Hoyo, J., Elliott, A., Sargatal, J., Christie, D.A. \& de Juana, E. (eds.). Handbook of the Birds of the World Alive. Lynx Edicions, Barcelona. (retrieved from http://www.hbw.com/node/58415 on 11 May 2016).

Tobias, J.A., Seddon, N., Spottiswoode, C.N., Pilgrim, J.D., Fishpool, L.D.C. \& Collar, N.J. (2010). Quantitative criteria for species delimitation. Ibis 152(4): 724-746.

\section{Recommended citation}

Boesman, P. (2016). Notes on the vocalizations of Blue Rock-thrush (Monticola solitarius). HBW Alive Ornithological Note 331. In: Handbook of the Birds of the World Alive. Lynx Edicions, Barcelona. (retrieved from http://www.hbw.com/node/1252744 on 24 October 2016). 